\title{
EXAMINATION OF MIDDLE CONCENTRATIONS OF OXYTETRACYCLINE RESIDUES IN COW MILK AFTER INTRAUTERINE APPLICATION
}

\author{
V. Vuković ${ }^{1}$, A. Kasalica ${ }^{2}$, M. Vićentijević ${ }^{1}$ \\ ${ }^{1}$ Institute of Veterinary Medicine of Serbia, 11070 Belgrade, Auto put 3, Republic of Srebia \\ ${ }^{2}$ Dairy Institute, 11070 Belgrade, Auto put 3, Republic of Serbia \\ Coresponding autor: vujadin.vukovic@gmail.com \\ Original scientific paper
}

Abstract: After intrauterine application of oxytetracycline in a dose of 2.0 g per cow, excretion of residues in milk was monitored using Resasurine test with Str. thermophilus and specific quantitative procedure (Vuković, 1999). Mean concentrations of oxytetracycline residues in milk samples, the total quantity per milking and the total quantity per cow were monitored.

Key words: oxytetracycline, residues, milk, intrauterine application, mean concentration

\section{Introduction}

Residues of antibiotics can be found in milk mainly after treatment of dairy cows (Adams, 1995; Jezdimirović, 2000), and usually can be detected by some biological methods. Most of these methods are qualitative, which can partially satisfy regulations (Miljković, 1977; WHO, 1999), but many questions still remain unanswered. First of all, we are referring to the disclosure more sensitive methods of detection; examine the hidden harmful effects of residues of antibiotics and to determine the lower thresholds of sensitivity of individual antibiotics as well as their combinations. Comprehensive approach to resorption, pharmacodynamics, pharmacokinetics and elimination of antibiotics residue through milk of dairy animals are also very important.

Thereby aim of this paper was to make a significant contribution through a form of quantification of antibiotics residues in milk, which opens new possibilities for expressing quantities of antibiotics excreted by milking, as well as total amount excreted through milk, which enables the determination of withdrawal and the percentage of applied dose antibiotics that are excreted into breast milk.

Also, with increasing of sensitivity and by quantification of the methods of detection attention must be paid to reduction, reducing costs and simplifying of 
implementation of procedures, as well as on education, frequency of verification, etc.

\section{Materials and Methods}

Five east Friesian cows intrauterine were treated with $2.0 \mathrm{~g}$ oxytetracycline hydrochloride (hereinafter oxytetracycline). Milk samples of treated cows were collected manually by milking cows by hand from every fourth udder into one collective sample and stored in the sterilized bottles in the refrigerator until the beginning of examination. Times of sampling were: 10, 22, 34, 46, 58, 70, 82 and 94 hours after treatment, ie of milking up to two consecutive negative findings.

Examination of the presence of oxytetracycline residues in milk was performed in a laboratory using the test Rezazurin Str. thermophilus, with a sensitivity level of $0.1 \mathrm{mg} / \mathrm{ml}$ (suspicious results) and $0.2 \mathrm{mg} / \mathrm{ml}$ (positive result) (Vuković, 2001; Vuković and Dugalić-Vrndić, 2004). For the quantification of the method milk samples were gradually or directly diluted with milk without antibiotics, making a direct and/or multi - stage dilution (Vuković, 2008). In this way we get the value of the dilution giving a positive or suspicious results (final value), and dilution values which give a negative result (first value). For the calculation were used formula (Vuković, 2008).

$$
K s=\frac{R a+(0,99 x R b}{2} x n
$$

Where is:

$\mathrm{K}_{\mathrm{s}}$ - mean concentration of oxytetracycline in milk $(\mu \mathrm{g} / \mathrm{ml})$;

$\mathrm{Ra}-$ final value of dilution, which gives a positive or suspicious result (koliko puta);

$\mathrm{Rb}$ - first value of dilution, which gives a negative result (koliko puta);

$\mathrm{n}-$ level of sensitivity for positive or suspicious values

Based on the milk production per milking $(\mathrm{ml})$ and obtained concentrations of oxytetracycline $(\mathrm{ml})$ secreted amount of every individual milking was calculated. By summing of these values during the experiment we calculated the total amount of secreted oxytetracycline. Using this data the percentage of applied dose that is excreted was calculate.

Obtained results were statistically processed over mean values and adjusted to the aim of research. 


\section{Results and Discussion}

Milk samples were taken from a total of five treated dairy cows and the retention time of residues of oxytetracycline in milk was monitored, the concentration of antibiotics in the function of milking per total secreted amount per time, as well as percentage of applied dose of oxytetracycline, which is secreted with milk of treated cows.

Oxytetracycline residues could be detected in milk samples of all of five cows. In addition, residues of antibiotics had a different retention time in milk (Table 1)

Table 1. - Time of sampling excretion time of oxytetracycline residues milk of treated cows (2g/i.u.)

\begin{tabular}{|c|c|}
\hline Cow number & $\begin{array}{c}\text { Time of sampling for oxytetracycline } \\
\text { residues excretion (hours) }\end{array}$ \\
\hline 1 & 58 \\
\hline 2 & 46 \\
\hline 3 & 58 \\
\hline 4 & 34 \\
\hline 5 & 70 \\
\hline $\bar{X}$ & $53,2(34-70)$ \\
\hline
\end{tabular}

Discontinuation of milk secretion of residues of oxytetracycline was between 34 and 70 hours of experiment and was averaged to 53.2 hours after giving the antibiotics (Table 1).

Mean concentrations of residues of oxytetracycline per $\mathrm{ml}$ of milk was monitored by times of observation. Table 2 shows that the maximum value of concentration of residues of oxytetracycline was on 22 hour if ranged from 1.0 to 2.2 ie an average of $1.64 \mathrm{mg} / \mathrm{ml}$. In the following these values decrease and in the 70 hour the average value was $0.08 \mu \mathrm{g} / \mathrm{ml}$.

Including the amount of milk by the muses, and the mean concentrations of residues of oxytetracycline per $\mathrm{ml}$ of milk, also, the amount excreted by milking oxytetracycline was highest on 22 hour when the experiment was approximately $11.480(8.000-14.700) \mu \mathrm{g} / \mathrm{milking}$, and the lowest average value was obtained at 70 hour when the experiment was $480 \mu \mathrm{g} /$ milking (Table 2).

Looking at the total amount of residues of oxytetracycline excreted during the entire period of abstraction, and the values ranged from 20.600 to 50.000 $\mu \mathrm{g} / \mathrm{time}$ excretion, and this value was an average of $34.760 \mu \mathrm{g} /$ time excretion (Table 2). 
Table 2. Oxytetracycline residue concentration in cow milk folowing single intrauterine application of dose of $2 \mathrm{~g} / \mathrm{cow}$

\begin{tabular}{|c|c|c|c|c|c|c|c|c|c|}
\hline \multirow{3}{*}{$\begin{array}{l}\text { Cow } \\
\text { number }\end{array}$} & \multirow{3}{*}{ Parameter } & \multirow{2}{*}{\multicolumn{6}{|c|}{$\begin{array}{l}\text { Oxytetracycline residues in milk - middle concentrations } \\
(\mu \mathrm{g} / \mathrm{ml} ; \mu \mathrm{g} / \text { milking })\end{array}$}} & \multirow{3}{*}{ Total } & \multirow{3}{*}{$\%$ dose } \\
\hline & & & & & & & & & \\
\hline & & 10 & 22 & 34 & 46 & 58 & 70 & & \\
\hline \multirow{2}{*}{1.} & $\mathrm{Km}(\mu \mathrm{g} / \mathrm{ml})$ & 1,4 & 1,7 & 0,9 & 0,5 & 0,3 & & & \\
\hline & $\mu \mathrm{g} /$ milking & 8.400 & 11.900 & 5.400 & 3.500 & 1.800 & & 31.000 & 1,55 \\
\hline \multirow{2}{*}{2.} & $\mathrm{Km}(\mu \mathrm{g} / \mathrm{ml})$ & 1,7 & 2,1 & 1,3 & 1,0 & & & & \\
\hline & $\mu \mathrm{g} /$ milking & 10.200 & 14.700 & 7.800 & 7.000 & & & 39.700 & 1,99 \\
\hline \multirow{2}{*}{3.} & $\mathrm{Km}(\mu \mathrm{g} / \mathrm{ml})$ & 1,2 & 1,2 & 1,3 & 0,8 & 0,8 & & & \\
\hline & $\mu \mathrm{g} /$ milking & 6.000 & 9.600 & 6.500 & 6.400 & 4.000 & & 32.500 & 1,62 \\
\hline \multirow{2}{*}{4.} & $\mathrm{Km}(\mu \mathrm{g} / \mathrm{ml})$ & 1,6 & 1,0 & 0,6 & & & & & \\
\hline & $\mu \mathrm{g} /$ milking & 9.600 & 8.000 & 3.600 & & & & 20.600 & 1,03 \\
\hline \multirow{2}{*}{5.} & $\mathrm{Km}(\mu \mathrm{g} / \mathrm{ml})$ & 1,8 & 2,2 & 1,9 & 1,9 & 0,9 & 0,4 & & \\
\hline & $\mu \mathrm{g} /$ milking & 9.000 & 13.200 & 9.500 & 11.400 & 4.500 & 2.400 & 50.000 & 2,50 \\
\hline \multirow[b]{2}{*}{$\bar{X}$} & $\mathrm{Km}(\mu \mathrm{g} / \mathrm{ml})$ & 1,54 & 1,64 & 1,20 & 0,84 & 0,4 & 0,08 & & \\
\hline & $\mu \mathrm{g} /$ milking & 8.640 & 11.480 & 6.560 & 5.660 & 2.060 & 480 & 34.760 & 1,74 \\
\hline
\end{tabular}

Legend:

$\overline{\mathrm{X}}$ - average value

$\mathrm{Km}$ - middle concentration of oxytetracycline residues in milk

Based on mean concetration of residues of oxytetracycline in milk ( $\mathrm{ml})$ and including milk amount per milking, amount of secreted oxytetracycline per milking was maximal at $22 \mathrm{nd}$ hour of the experiment, and the average value was 11.480 $(8.000-14.700) \mu \mathrm{g} / \mathrm{milking}$. Minimal average value was $480 \mu \mathrm{g} / \mathrm{milking}$ at $70^{\text {th }}$ hour of the experiment (Table 2).

Total amount of residues of oxytetracycline secreted were $20.600-50.000$ $\mu \mathrm{g} / \mathrm{time}$ of secretion with the average value of $34.760 \mu \mathrm{g} / \mathrm{time}$ of secretion (Table 2).

Percentage values of aplied dose of oxytetracycline secreted by milk of treated cows were obtained based on total secreted amount per time of experiment. That values were $1,03-2,5 \%$ respectevely and average value was $1,74 \%$ i.u. of applied dose of $2 \mathrm{~g}$ oxytetracycline (table 2).

Obtained results were not in accordance with results Keneene et al (1986). Namely after giving of i.u. dose of $3 \mathrm{~g}$ oxytetracycline, residues could be detected after 12,5 - 44 hours. Similar results were obtained by Prasad et al. (1987) after application of i.u. dose og $5 \mathrm{mg} / \mathrm{kg}$ (cow) they detected resudes after 3 and 12 hours.

Results presented in this paper are particulary in accordance with some other authors: Gedek (1975), Slee and Brightling (1981), Vuković (1991). They confirmed that after giving of i.u. dose of $1,0 \mathrm{~g}$ (per $\mathrm{kg}$ cow) residues of antibiotcs can be found (secreted) in 4 - 5 milking. 
$0,73-5,50 \%$ of dose secreted with milk of treated cows can be found after giving of i.u. dose of $1,0 \mathrm{~g} / \mathrm{kg}$ (Vuković, 1991) which is similar to our results with double dose.

\title{
Conclusion
}

After giving a single intrauterine dose of $2 \mathrm{~g} /$ cow oxytetracycline, residues of antibiotics are secreted in milk of treated animals in a time of 34 to 79 hours, an average of 53.2 hours. In addition, the mean concentration of oxytetracycline residues ranged from $0.08 \mathrm{mg} / \mathrm{ml}$ (70th hour of experiment) to $1.64 \mathrm{mg} / \mathrm{ml}$ (22nd hour of experiment).

The values of total amount of the secreted antibioitics per milking ranged from $480 \mathrm{mg} / \mathrm{milking}$ (70 th hour of experiment) to 11,480 mg/milking (22nd hour of experiment).

The average value of total amount of the secreted oxytetracycline per milking during the period of secretion was $34,760 \mathrm{mg} / \mathrm{secretion}$ time, with a variation interval of 20,600 to $50,000 \mathrm{mg} / \mathrm{secretion}$ time which is $1.74 \%$ (1.03 to 2.5) of the administered dose.

\section{Acknowledgment} 2014).

Project MNTR Government of Serbia no. 46009 for the period (2011-

\section{Ispitivanje srednje koncentracije rezidua oksitetraciklina u mleku krava posle intrauterine aplikacije}

\author{
V. Vuković, A. Kasalica, M. Vićentijević
}

\section{Rezime}

Posle intrauterinog davanja oksitetraciklina u dozi od 2 g/grlu krava, praćeno je izlučivanje rezidua u mleku korišćenjem metode Rezazurin testa sa Str. thermophilus i specifičnog kvantitativnog postupka (Vuković, 1999). Srednja koncentracija rezidua oksitetraciklina u uzorcima mleka, ukupna količina po muži i ukupna količina po grlu krava bile su praćene. 


\section{References}

ADAMS R.H. (1995): Veterinary pharmacology and therapeutics. 7. edition, Iowa State Univ. Press/Ames, Iowa.

GEDEK W., FASTNER S., GUNZLER O. (1975): Antibiotics residues in bovine milk after intrauterine administration of commercial preparations. Tierarztliche Msxchau, 30, 5, 223-227.

JEZDIMIROVIĆ M. (2000): Veterinarska farmakologija. II prerađeno i dopunjeno izdanje, Fak. vet. med., Beograd.

KANEENE J.B. et al. (1986): Drug residues in milk after i.u. injection of oxitetracycline, lincomycin-spectinomycin and povidone iodide in cows with metritis. Am. J. of Vet. Resear., 47, 6, 1363-1365.

MILJKOVIĆ V. (1977): Higijena i tehnologija mleka. Fakultet veterinarske medicine, Beograd.

PRASAD S., JAYACHANDRAN C., SINGH M. (1987): Pharmacochinetic of oxitetracycline in dairy cows. Indian J. of Aim. Sci., 57, 2, 106-110.

SLEE K.J., BRIGHTLING P. (1981): Antibacterial activiti of cows milk following therapy with oxytetracycline uterine pessories. Australian Vet. J., 57, 3, 143-144.

VUKOVIĆ V. (1991): Residue resorption and secretion of penicillin, streptomycin and oxytetracycline in milk after intrauterine administration. Doctoral thesis, Faculty of Veterinary Medecine, Belgrade.

VUKOVIĆ V. (2001): Investigations of sensitivity level of Delvo and Resasurine test for presence of penicillin and oxytetracycline in milk. Vet. glasnik, 55, 1-2, 5559.

VUKOVIĆ V. (2008): Kvantitativno dokazivanje rezidua antibiotika u mleku. Samostalno autorsko izdanje. ISBN 978-86-911481-1-9, Antika, Beograd.

VUKOVIĆ V. (2008): Razblaženja uzorka mleka za kvantitativno dokazivanje rezidua antibiotika. Samostalno autorsko izdanje. Antika, Beograd.

VUKOVIĆ V., DUGALIĆ-VRNDIĆ N. (2004): Rezidue oksitetraciklina u mleku krava posle intrauterine aplikacije. Vet. glasnik Srbije, Beograd, 58, 1-2, 95-103.

VUKOVIĆ V., ŽIVANOV D. (1992): Rezidue oksitetraciklina u mleku krava posle i.u. davanja u dozi od 1 g. V Savetovanje veterinara Srbije, Kopaonik, Kratki sadržaji radova, br. 87, 58 .

WHO (1999): Residues of some veterinary drugs in animals and foods. Monographs prepared by the Fiftyeth meetting of the Joint FAO/WHO Expert Committee on Food Aditives, Rome, 2-11. 